\title{
БИОЛОГИЧЕСКАЯ ХАРАКТЕРИСТИКА НОВОГО СОРТА ОЗИМОГО ЯЧМЕНЯ РАДАНА
}

\author{
Кичка М.Н., Кречун И.В. \\ Научно-исследовательский институт полевых культур “Селекция” Бэлиь, Молдова
}

\begin{abstract}
In this article the description of new variety of winter barley Radana are presented. This variety has been obtained by hybridization method and multiple individual selection. It has the high and stable productivity on years. On the average for the 2016-2019 years productivity made him to 5,55t/ha.
\end{abstract}

Key words: winter barley, hibridization, variety, yield.

\section{Введение}

Рост урожайности сельскохозяйственных культур осуществляется в результате улучшения условий их возделывания и за счёт новых более продуктивных сортов. Мировая практика и данные научно-исследовательских учреждений свидетельствуют, что в общем повышении урожайности полевых культур на долю сорта приходится от 25 до 50\%[1,2]. Поэтому создание и внедрение в производство новых сортов сельскохозяйственных культур имеющих приемущество по урожайности является основной задачей сельскохозяйственной науки[3]. Важно создание сортов сочетающих высокий уровень урожайности с устойчивостью к неблагоприятным условиям окружающей среды[2,4 ]. В связи с запросами производства, мы нацелены создавать продуктивные и устойчивые к неблагоприятным факторам окружающей среды сорта озимого ячменя,что обеспечит их стабильную по годам урожайность.

\section{Материал и методика}

Исследования проводились в конкурсном сортоиспытании 10-ти польного селекционного севооборота НИИПК «Селекция» по предшественнику горох на зерно. Методом создания исходного материала была внутривидовая гибридизация. Посев озимого ячменя проводился сеялкой ССФК-7 в оптимальные сроки. Повторность 4-х кратная. Размер учётной делянки - 10 м2. Стандартные сорта размещали через 10 номеров. Уборка проводилась комбайном “Сампо-130”. Фенологические наблюдения, оценки и анализы проводили по общепринятым методикам. Полученные данные обрабатывали методом дисперсионного анализа [5].

\section{Результаты и обсуждения}

Сорт Радана создан в МолдНИИПК методом многократного индивидуального отбора из гибридной популяции, полученной от скрещивания сортов (Мироновский 87 х Д-71).

Элитное растение было выделено в 2005 году и далее образец изучался во всех звеньях селекционного процесса. В 2014 году данный селекционный образец под названием Радана был передан в ГСИ и изучался на всех сортоучастках нашей страны с 2015 по 2017гг. 
Таблица 1. Урожайность озимого ячменя Radana в I зоне нашей страны в среднем за 2015-2017г.г., т/га.

\begin{tabular}{|c|c|c|c|c|}
\hline \multirow[b]{2}{*}{ Сорта } & \multicolumn{2}{|c|}{ Северная зона } & \multirow{2}{*}{$\begin{array}{c}\text { Средняя } \\
\text { по зоне } \\
\end{array}$} & \multirow{2}{*}{$\begin{array}{l}\text { В \% } \\
\text { K st }\end{array}$} \\
\hline & Высока & Пеления & & \\
\hline $\begin{array}{c}\text { Сред. стандарт за } 2 \\
\text { года }\end{array}$ & 6,68 & 7,09 & 6,89 & 100,0 \\
\hline Radana & 7,81 & 7,14 & 7,47 & 108,5 \\
\hline
\end{tabular}

Согласно данным таблицы 1 видно, что средняя урожайность сорта Радана за 2015-2017гг в I зоне нашей страны составила в среднем 7,47 т/га, превысив государственные стандарты в среднем на 8,5\%. И с 2018 года сорт районирован в первой зоне нашей страны.

Апробационные признаки: разновидность pallidum; колос цилиндрический, полупрямостоячий,средней длинны(7,0-9,0см),и средней плотности; длинные,зазубренные, соломенно-желтые, слегка прижаты к колосу; переход цветочной чешуи в ость постепенный; зерно среднее, удлиненное, желтого цвета, масса 1000 семян в среднем 45,7 г, щетинка у основания зерна войлочная. В период восковой спелости отсутствует антоциановая окраска стебля и остей.

Хозяйственно-биологические признаки: данный сорт относится к группе полуинтенсивных сортов. По типу развития - озимый .Сорт раннеспелый, вегетационный период 214-236 суток, созревает на 5-7 дней раньше предшествующих ему сортов (Скынтея, Тезаур, Ексчелент ). Высота растений колеблется в пределах 8692 см, устойчив к полеганию. Морозо-зимостойкость и устойчивость к засухе высокая. Содержание протеина - 12,9-13,6\%.

Данный сорт характеризуется также достаточно высокой и стабильной продуктивностью.

Урожайность данного сорта в среднем за последние 4 года (Таб.2) в конкурсном сортоиспытании составила 5,55т/га, превысив стандарты Ексчелент и Тезаур на 0,20 и о,15т/га. Генетический потенциал продуктивности данного сорта - 8,0т/га.

Срок посева осенью -первая/вторая декады октября . Норма высева 4,0-4,5млн. всхожих семян на гектар.

Таблица 2. Урожайность перспективных сортов озимого ячменя в КСИ за 2016-2019г.г.

\begin{tabular}{|c|c|c|c|c|c|c|c|}
\hline \multirow{2}{*}{ Сорта } & \multicolumn{6}{|c|}{ Урожайность } & \multirow{2}{*}{ Вегетац. } \\
\cline { 2 - 6 } & 2016 & 2017 & 2018 & 2019 & Высота \\
растений \\
\cline { 3 - 7 }
\end{tabular}




\section{Выводы}

1. Данный сорт выделяется высокой морозо-зимостойкостью и засухоустойчивостью и имеет хорошую и стабильную по годам продуктивность.

2. В среднем за 2016-2019гг урожайность его составила 5,55т/га.

\section{Библиография}

1. Румянцев А.В. - Создание и совершенствование сортов зерновых и кормовых культур в условиях Среднего Поволжья// Аграрный вестник Юго-Востока. Саратов, 2009, №1 - С.20-22.

2. Кочмарский В.С., Гудзенко В.М., Каунец В.П. - Отечественный ячмень - новые сорта способны противостоять стихии и засухам// Земледелие. 2011,№3 - С. 16-18.

3. Глуховцев В.В. - Особенности адаптивной селекции зерновых культур в условиях Среднего Поволжья// Аграрный вестник Юго-Востока. Саратов , 2009, №1. С.12-14.

4. Жученко А.А. - Адаптивный потенциал культурных растений. - Кишинёв, “ Штиинца “, 1998. - С.283,749.

5. Б.А. Доспехов. Методика полевого опыта. М. “Колос” 1979. 